\title{
Role of Interventional Radiology in the Treatment of Patients with Neuroendocrine Metastases in the Liver
}

\author{
Larry K. Kvols, MD; Kiran K. Turaga, MD, MPH; Jonathan Strosberg, MD; and Junsung Choi, MD; Tampa,
} Florida

\begin{abstract}
Key Words
Neuroendocrine carcinomas, carcinoid tumors, liver metastases, hepatic artery embolization, chemoembolization, radiofrequency ablation
\end{abstract}

\begin{abstract}
Management of liver metastasis from neuroendocrine tumors routinely includes an interventional radiologist. Hepatic artery embolization, either bland (transarterial embolization) or with chemotherapy (transarterial chemoembolization), has been shown to improve response rates in neuroendocrine metastases to the liver. Radiofrequency ablation, cryotherapy, and percutaneous alcohol ablation are important adjuncts or alternative treatments to surgical debulking. In this article, the authors examine important techniques in the armamentarium of the interventional radiologist. (JNCCN 2009;7:765-772)
\end{abstract}

The liver is the predominant site of metastatic disease in gastrointestinal neuroendocrine tumors. In the early 1980s, hepatic artery ligation was recommended for management of patients with symptomatic carcinoid syndrome. ${ }^{1}$ In fact, early studies by Moertel et al. ${ }^{1}$ showed objective regressions in $60 \%$ of patients with metastatic carcinoid to the liver using occlusion alone versus $80 \%$

From the H. Lee Moffitt Cancer Center and Research Institute, Tampa, Florida.

Submitted February 2, 2009; accepted for publication April 28, 2009.

Dr. Kvols has disclosed that he is a consultant for and on the advisory board and speakers' bureau for Novartis Pharmaceuticals Corporation (compensation totals more than $\$ 10,000$ ). Drs. Turaga, Strosberg, and Choi have disclosed that they have no interests, arrangements, or affiliations with the manufacturers of any products discussed in the article or their competitors.

Correspondence: Larry K. Kvols, MD, Neuroendocrine Oncology, H. Lee Moffitt Cancer Center and Research Institute, 12902 Magnolia Drive, Tampa, FL 33612. E-mail: larry.kvols@moffitt.org with chemotherapy added (alternating doxorubicin plus dacarbazine and streptozocin plus fluorouracil). ${ }^{1}$ Over the ensuing decades, selective lobar hepatic artery embolization or chemoembolization was found to be significantly more tolerable than surgical ligation. ${ }^{2,3}$ Several ablative techniques were also developed over the past 2 decades, causing interventional radiologists to become important members of the multidisciplinary team managing patients with neuroendocrine tumors. These developments are reflected in the current guidelines of the NCCN, which list both embolization and ablative techniques for managing patients with metastatic neuroendocrine tumors (Table 1$){ }^{4}$

\section{Hepatic Artery Embolization}

Although surgery remains the preferred procedure for patients with localized hepatic metastasis, it is rarely an option (10\%-20\%) for those with disseminated or multifocal disease. ${ }^{5-7}$ Although liver transplantation has been reported in sporadic series for multifocal metastatic neuroendocrine tumors, the lack of donor livers and variable survival rate $(36 \%-87 \%)^{6,8,9}$ reported make it a nonviable option for most patients. The rationale for hepatic artery embolization is based on the observation that these hypervascular tumors derive most of their blood supply from the hepatic artery. ${ }^{5,10}$ Moreover, hepatic metastases are known to compress adjacent portal sinusoids, which are the primary blood supply sites for normal liver tissue. In patients with progressive or symptomatic metastases predominantly confined to the liver, embolization or chemoembolization of the hepatic artery can be recommended as first-line therapy.

Typically, each lobe of the liver is embolized selectively. 
Kvols et al.

\begin{tabular}{|c|c|c|}
\hline $\begin{array}{l}\text { Type of Metastatic } \\
\text { Neuroendocrine Tumor }\end{array}$ & $\begin{array}{l}\text { First-Line Therapy in } \\
\text { Asymptomatic Patients }\end{array}$ & First-Line Therapy in Symptomatic Patients \\
\hline $\begin{array}{l}\text { Carcinoid: } \\
\text { foregut (esophagus, } \\
\text { stomach, bronchial) }\end{array}$ & $\begin{array}{l}\text { Surgery if possible } \\
\text { Observation }\end{array}$ & $\begin{array}{l}\text { Somatostatin analogues } \\
\text { Surgery if possible } \\
\text { RFAlalcohol ablation/cryoablation }\end{array}$ \\
\hline $\begin{array}{l}\text { Midgut (small intestine, } \\
\text { colon) }\end{array}$ & $\begin{array}{l}\text { Surgery if possible } \\
\text { Observation }\end{array}$ & $\begin{array}{l}\text { Somatostatin analogues } \\
\text { Surgery if possible } \\
\text { RFA/alcohol ablation/cryoablation } \\
\text { Chemoembolization (if advanced or progressive disease) }\end{array}$ \\
\hline Hindgut (colon, rectum) & $\begin{array}{l}\text { Surgery if possible } \\
\text { Observation }\end{array}$ & $\begin{array}{l}\text { Somatostatin analogues } \\
\text { Surgery if possible } \\
\text { RFAlalcohol ablation/cryoablation }\end{array}$ \\
\hline $\begin{array}{l}\text { Noncarcinoid tumors } \\
\text { (Islet cell tumors): } \\
\text { gastrinoma, insulinoma, } \\
\text { vipoma }\end{array}$ & $\begin{array}{l}\text { Surgery if possible } \\
\text { Observation }\end{array}$ & $\begin{array}{l}\text { Somatostatin analogues } \\
\text { Surgery if possible } \\
\text { RFA/alcohol ablation/cryoablation } \\
\text { Chemoembolization (if advanced or progressive disease) } \\
\text { Chemotherapy }\end{array}$ \\
\hline
\end{tabular}

*Based on the NCCN Clinical Practice Guidelines in Oncology: Neuroendocrine Tumors, Version 1, 2009, highlighting the role of interventional radiology (in this issue; to view the most recent version of these guidelines, visit the NCCN Web site at www.ncen.org).

Abbreviation: RFA, radiofrequency ablation.

Thus, the entire liver can be treated in 2 to 3 stages, depending on the extent of disease. Chemotherapeutic agents are often added to the embolic material (doxorubicin, streptozocin); however, whether addition of chemotherapy improves outcomes is still uncertain.

\section{Embolization Procedure}

A diagnostic celiac angiogram is performed to identify the hepatic vasculature, patency of the portal vein, and number and location of hepatic metastases. Presence of portal vein occlusion and ascites are considered relative contraindications for the procedure. A superior mesenteric arteriogram is performed in the presence of a replaced or accessory hepatic artery. Subcutaneous octreotide is often administered immediately before the procedure in patients with the carcinoid syndrome to prevent acute release of serotonin into the circulation. Subselective catheterization of the right or left hepatic artery is performed using an angled 5 Fr catheter or 3 Fr microcatheter coaxially through the $5 \mathrm{Fr}$ angled catheter placed in the origin of the celiac artery or superior mesenteric artery.

Embolization is performed under fluoroscopy. Various particulate materials have been used, including 250- to 355- $\mu \mathrm{m}$ diameter polyvinyl alcohol particles and 500- to 700- $\mu \mathrm{m}$ diameter microspheres. For chemoembolization, an emulsion of a cytotoxic drug such as doxorubicin, mitomycin $\mathrm{C}$, or cisplatin, or a combination of these, is dissolved in $10 \mathrm{~mL}$ of normal saline $(0.9 \%)$ combined with $10 \mathrm{~mL}$ of iodized oil, which is injected into the subselected right or left hepatic artery. The embolization procedure is performed until near complete stasis of flow. Usually the liver lobe with the bulkiest disease is embolized first. Antiemetics and adequate analgesia should be provided, and preoperative intravenous hydration is important. Perioperative antibiotics should be administered (e.g., levofloxacin and flagyl) for at least 72 hours to prevent abscess formation. Individual embolizations are spaced 4 weeks apart, and most patients complete their embolizations in 2 or 3 stages. ${ }^{11}$ Follow-up imaging studies are typically performed 1 to 2 months after the last embolization.

Minor complications are common, such as transient nausea, vomiting $(50 \%-70 \%)$, abdominal pain $(50 \%-60 \%)$, and fevers $(30 \%-60 \%) .{ }^{11}$ Hepatic transaminases typically increase, peaking 2 to 3 days after each embolization. ${ }^{11}$ Most side effects resolve within 1 week. Acute hypertension is occasionally observed in patients with carcinoid syndrome during or immediately after the embolization procedure. Elevated liver enzymes are also seen (100\% peak usually within 2-3 days). Severe complications, such as gastric perforation, gastritis, bleeding peptic ulcers, and duodenitis, can usually be avoided with highly selective catheterization. Hepatic and renal failure has also been reported after repeated embolization treatments. ${ }^{12}$ 


\section{Response Rates}

Hepatic arterial embolization has been shown to provide symptomatic relief in $59 \%$ to $100 \%$ of cases (Table 2). Symptomatic responses occur as a result of reduction in hepatic tumor burden and decrease of hormonal output in functional tumors. ${ }^{13-16}$ For example, major decreases in 5-hydroxyindoleacetic acid (5-HIAA) levels (> 50\% reduction) occur in $51 \%$ to $91 \%$ of patients with carcinoid syndrome. ${ }^{16-20}$

Objective tumor responses have been noted in $33 \%$ to $80 \%$ of patients (Table 3 ). This is a heteroge- neous rate caused by variation in the type of tumors, choice of cytotoxic agent, and concomitant use of somatostatin analogues. The extent of liver involvement has been proposed to be predictive of tumor response. ${ }^{18}$

Novel Strategies in Hepatic Artery Embolization

Radioembolization using yttrium 90 as a source of beta energy is currently approved in the United States for the treatment of hepatocellular and colorectal cancers. Yttirum 90 is a pure beta emitter that decays over a half-life of 64.2 hours. During manufacturing, yttrium 89 is incorporated into a stable glass matrix or

\begin{tabular}{|c|c|c|c|c|c|c|}
\hline Author & Year & $\begin{array}{l}\text { Number } \\
\text { of } \\
\text { Patients }\end{array}$ & $\begin{array}{l}\text { Tumor } \\
\text { Type }\end{array}$ & Chemotherapy & $\begin{array}{l}\text { Symptomatic } \\
\text { Response \% (in } \\
\text { Symptomatic } \\
\text { Patients) }\end{array}$ & $\begin{array}{l}\text { Biomarker } \\
\text { Response }>\mathbf{5 0} \%\end{array}$ \\
\hline Ruszniewski et al. ${ }^{16}$ & 1993 & 23 & $\begin{array}{l}\text { 18: CT } \\
\text { 5: ICC }\end{array}$ & Adriamycin & 73 & 57 \\
\hline Stokes et al. ${ }^{21}$ & 1993 & 20 & $\begin{array}{l}\text { 13: CT } \\
\text { 7: ICC }\end{array}$ & Adriamycin & 100 & 90 \\
\hline Therasse et al. ${ }^{17}$ & 1993 & 23 & Carcinoid & Adriamycin & 100 & 91 \\
\hline Perry et al. ${ }^{22}$ & 1994 & 39 & Carcinoid & Adriamycin & 90 & 79 \\
\hline Clouse et al. ${ }^{20}$ & 1994 & 14 & Carcinoid & Adriamycin & 90 & 69 \\
\hline Diaco et al. ${ }^{19}$ & 1995 & 10 & Carcinoid & $\begin{array}{l}\text { Cisplatin, } \\
\text { mitomycin, } \\
\text { adriamycin }\end{array}$ & 100 & - \\
\hline Diamandidou et al. ${ }^{23}$ & 1998 & 20 & $\begin{array}{l}\text { 17: CT } \\
\text { 3: ICC }\end{array}$ & Cisplatin & 67 & 73 \\
\hline Drougas et al. ${ }^{24}$ & 1998 & 15 & Carcinoid & $\begin{array}{l}\text { Cisplatin, } \\
\text { mitomycin, } \\
\text { adriamycin }\end{array}$ & 67 & 100 \\
\hline Desai et al..$^{25}$ & 2000 & 34 & Carcinoid & $\begin{array}{l}\text { Adriamycin, } \\
\text { mitomycin }\end{array}$ & 78 & 60 \\
\hline Dominguez et al. ${ }^{13}$ & 2000 & 15 & $\begin{array}{l}\text { 8: CT } \\
\text { 7: ICC }\end{array}$ & Streptozocin & $\begin{array}{l}60 \\
75\end{array}$ & 50 \\
\hline $\begin{array}{l}\text { Ruszniewski and } \\
\text { Malka } 26\end{array}$ & 2000 & 15 & $\begin{array}{l}\text { 8: CT } \\
\text { 7: ICC }\end{array}$ & Streptozocin & 67 & 50 \\
\hline Roche et al. ${ }^{18}$ & 2003 & 14 & $\begin{array}{l}\text { 10: CT } \\
\text { 4: Other }\end{array}$ & Adriamycin & 70 & 75 \\
\hline Roche et al. ${ }^{27}$ & 2004 & 64 & CT/ICC & Adriamycin & 59 & - \\
\hline Touzios et al. ${ }^{28}$ & 2005 & 18 & 8: CT & $\begin{array}{l}\text { Cisplatin, } \\
\text { mitomycin, } \\
\text { adriamycin }\end{array}$ & 88 & - \\
\hline Marrache et al..$^{29}$ & 2007 & 67 & $\begin{array}{l}\text { 48: CT } \\
\text { 19: ICC }\end{array}$ & $\begin{array}{l}\text { Streptozocin, } \\
\text { adriamycin }\end{array}$ & 91 & 65 \\
\hline Ho et al. ${ }^{30}$ & 2007 & 46 & $\begin{array}{l}\text { 31: CT } \\
\text { 15: ICC }\end{array}$ & $\begin{array}{l}\text { Cisplatin, } \\
\text { mitomycin, } \\
\text { adriamycin }\end{array}$ & $\begin{array}{l}78 \\
75\end{array}$ & - \\
\hline
\end{tabular}

Abbreviations: CT, carcinoid tumors; ICC, islet cell tumors. 
Kvols et al.

\begin{tabular}{|c|c|c|c|c|}
\hline Study & Year & Tumor Histology & Therapy & $\mathrm{CR}+\mathrm{PR} \%$ \\
\hline Hajarizadeh et al. ${ }^{31}$ & 1992 & Carcinoid & TACE & $50(4$ of 8$)$ \\
\hline Ruszniewski et al. ${ }^{16}$ & 1993 & Carcinoid & TACE & 33.3 (6 of 18$)$ \\
\hline Therasse et al. ${ }^{17}$ & 1993 & Carcinoid & TACE & 35 (6 of 17 ) \\
\hline Clouse et al. ${ }^{20}$ & 1994 & Carcinoid/ICC & TACE & 95 (19 of 20$)$ \\
\hline Diaco et al. ${ }^{19}$ & 1995 & Carcinoid & TACE & $60(6$ of 10$)$ \\
\hline Drougas et al. ${ }^{24}$ & 1998 & Carcinoid & TACE & 6.7 (1 of 15) \\
\hline Kim et al. ${ }^{32}$ & 1999 & Carcinoid & TACE & 25 (4 of 16) \\
\hline Dominguez et al. ${ }^{13}$ & 2000 & Carcinoid & TACE & $50(4$ of 8$)$ \\
\hline Roche et al. ${ }^{18}$ & 2003 & Carcinoid & TACE & $43(6$ of 14$)$ \\
\hline Gupta et al. ${ }^{33}$ & 2003 & Carcinoid & TACE & 44.4 (12 of 27$)$ \\
\hline Desai et al. ${ }^{25}$ & 2001 & Carcinoid/ICC & TACE & 45 (18 of 34) \\
\hline Kress et al. ${ }^{34}$ & 2003 & Carcinoid/ICC & TACE & $7(2$ of 26$)$ \\
\hline Fiorentini et al. ${ }^{35}$ & 2004 & Carcinoid/ICC & TACE & 70 (7 of 10$)$ \\
\hline Marrache et al. ${ }^{29}$ & 2007 & Carcinoid/ICC & TACE & 37 (14 of 38 ) \\
\hline Artinyan et al..$^{36}$ & 2008 & Carcinoid/ICC & TACE & $22(6$ of 27$)$ \\
\hline Carrasco et al. ${ }^{37}$ & 1983 & ICC & TACE & 100 (3 of 3 ) \\
\hline Mavligit et al. ${ }^{38}$ & 1993 & ICC & TACE & $80(4$ of 5$)$ \\
\hline Ruszniewski et al. ${ }^{16}$ & 1993 & ICC & TACE & $0(0$ of 5$)$ \\
\hline Kim et al. ${ }^{32}$ & 1999 & ICC & TACE & 50 (7 of 14$)$ \\
\hline Dominguez et al. ${ }^{13}$ & 2000 & ICC & TACE & $57(4$ of 7$)$ \\
\hline Gupta et al. ${ }^{33}$ & 2003 & ICC & TACE & 50 (11 of 22$)$ \\
\hline Carrasco et al. ${ }^{37}$ & 1983 & Carcinoid & TAE (+ IFN) & $83(5$ of 6$)$ \\
\hline Hanssen et al. ${ }^{39}$ & 1989 & Carcinoid & TAE & $71(5$ of 7$)$ \\
\hline Moertel et al. ${ }^{1}$ & 1994 & Carcinoid & TAE & 69.6 (16 of 23 ) \\
\hline Wangberg et al. ${ }^{40}$ & 1996 & Carcinoid & TAE & 42.5 (17 of 40$)$ \\
\hline Eriksson et al. ${ }^{41}$ & 1998 & Carcinoid & TAE & 38 (11 of 29$)$ \\
\hline Loewe et al..$^{42}$ & 2003 & Carcinoid & TAE & 73 (16 of 22$)$ \\
\hline Gupta et al..$^{33}$ & 2003 & Carcinoid & TAE & 81 (34 of 42 ) \\
\hline Strosberg et al. ${ }^{11}$ & 2006 & Carcinoid/ICC & TAE & 48 (11 of 23 ) \\
\hline Carrasco et al..$^{37}$ & 1983 & ICC & TAE & $50(3$ of 6$)$ \\
\hline Moertel et al. ${ }^{1}$ & 1994 & ICC & TAE & $82(14$ of 17$)$ \\
\hline Eriksson et al. ${ }^{41}$ & 1998 & ICC & TAE & 17 (2 of 12) \\
\hline Gupta et al. ${ }^{33}$ & 2003 & ICC & TAE & 28 (9 of 32$)$ \\
\hline Ajani et al. ${ }^{3}$ & 1988 & ICC & TAE & 60 (12 of 20$)$ \\
\hline Ho et al. ${ }^{30}$ & 2007 & Carcinoid/ICC & TACE/TAE & 46 (15 of 33) \\
\hline Ruutiainen et al. ${ }^{43}$ & 2007 & Carcinoid/ICC & TACE/TAE & 49 \\
\hline Christante et al. ${ }^{44}$ & 2008 & Carcinoid/ICC & TACE + chemo-infusion & 80 (62 of 77) \\
\hline McStay et al. ${ }^{45}$ & 2005 & Carcinoid/ICC & Y-90 radioembolization & 16 (3 of 19) \\
\hline King et al. ${ }^{46}$ & 2008 & Carcinoid/ICC & Y-90 radioembolization & 50 (17 of 34$)$ \\
\hline Kennedy et al. ${ }^{47}$ & 2008 & Carcinoid/ICC & Y-90 radioembolization & 63.2 (93 of 148$)$ \\
\hline Murthy et al. ${ }^{48}$ & 2008 & Carcinoid/ICC & Y-90 radioembolization & $12(1$ of 8$)$ \\
\hline
\end{tabular}

Abbreviations: ICC, islet cell tumors; CR, complete response; IFN, interferon alpha; PR, partial response; TACE, transarterial chemoembolization; TAE, transarterial (bland) embolization; Y-90, yttrium 90. 
resin and is converted to yttrium 90 through neutron bombardment. Patients with myelosuppression and renal failure are generally excluded.

Preprocedural studies, including visceral angiogram for mapping the vascular supply to the liver, is performed approximately a week before radioembolization. Any vessels supplying the gastrointestinal tract that must be avoided are embolized before treatment. Technetium 99m isotope-labeled macro-albumin similar in size to the radioembolization particle is then infused through the catheter, and single-photon emission computed tomography (SPECT) gamma imaging is obtained to evaluate for possible shunting of microspheres to the lungs or gastrointestinal tract. The approach to radioembolization is similar to hepatic artery embolization. However, the goal of radioembolization is to cause tumor necrosis through radiation exposure. Cell death through radiation requires normal oxygen tension. Therefore, stasis of flow is avoided during radioembolization. Radioembolic agents are typically infused to both lobes rather than staged using a unilobar approach.

In a retrospective multi-institutional study, radioembolization showed complete imaging response in $2.7 \%$ of cases, partial response in $60.5 \%$, stable disease in $22.7 \%$, disease progression in $4.9 \%$, and median survival of 70 months. ${ }^{47} \mathrm{~A}$ study comparing the use of glass versus resin microspheres for metastatic neuroendocrine tumors showed a $92 \%$ and $94 \%$ response rate at 6 months, with a median survival of 22 and 28 months, respectively. Grade III/IV toxicity was experienced by $14 \%$ of patients. ${ }^{49}$ The side effect profile includes renal failure, postembolization syndrome, and bone marrow suppression. The postembolization syndrome occurs in only $18 \%$ of cases due to arterial flow stasis.

\section{Radiofrequency Ablation, Cryoablation, and Percutaneous Alcohol Injection}

Patients with limited numbers of unresectable liver metastases may benefit from interventional ablative techniques. Tumor ablations are often performed intraoperatively, in conjunction with surgical resection. Alternatively, they may be performed percutaneously, depending on the number and location of the hepatic metastases.

\section{Radiofrequency Ablation}

Radiofrequency ablation (RFA) involves converting radiofrequency waves to heat using a high alternating current of $460 \mathrm{kHz}$, which passes from an uninsulated tip into surrounding tissues and causes ionic vibration after the change in the direction of the current. Friction heating caused by the ionic vibration and tumor death occurs at around $60^{\circ} \mathrm{C}$. The size of the ablation zone is dependent on the size of the probe. Currently the largest ablation zone is approximately $7 \mathrm{~cm}$.

\section{Technique}

RFA can be performed under local anesthesia with sedation or under general anesthesia. Using ultrasound or CT image guidance, an RFA needle probe is inserted into the liver metastasis. The position of the probe is confirmed on multiplanar imaging to verify true centricity of the probe. The tines of the probe (e.g., RITA Angiodynamics, Queensbury, New York; Cooltip RFA device, Valleylab, Colorado; RF 3000, Boston Scientific, Natick, Massachusetts) are then advanced to generate a thermal ablation zone, including the tumor and a margin. Anatomic proximity to blood vessels can act as a heat sink, thus causing loss of effect, and temperatures are continuously monitored on each of the probe tines. Once adequate heating is achieved for the specified duration based on size of the ablation zone, the tines are withdrawn and the probe removed. Similar procedures are repeated for other lesions.

Patients are usually monitored postoperatively for pain and fevers. Other complications include bile leakage and pleural effusion. ${ }^{50}$ Radiologic followup is established and the images are reviewed by an experienced radiologist.

\section{Response}

Complete or significant symptom response has been shown in $69 \%$ to $80 \%$ of patients treated with RFA, and local control was achieved in $74 \%$ of the symptomatic patients. ${ }^{12}$ Complications associated with RFA are usually restricted to those at the site of needle entry, such as pneumothorax and neuritis, in addition to liver abscesses.

\section{Percutaneous Ethanol Injection}

Percutaneous alcohol ablation has been described in the treatment of hepatocellular carcinoma and metastatic colorectal adenocarcinomas, in which necrosis is achieved in $50 \%$ of cases. ${ }^{51,52}$ Alcohol acts by causing coagulative necrosis, which then leads to thrombosis of small vessels accompanied by formation of fibrotic tissue. The main concern regarding ethanol 
use is its inhomogenous distribution. Overall, percutaneous ethanol injection has largely been replaced by RFA, which typically achieves necrosis in fewer sessions and is associated with lower rates of recurrence. ${ }^{52,53}$ Therefore ethanol ablation is generally reserved for metastases abutting large vessels susceptible to the heat-sink effect, and adjacent to central bile ducts in which strictures can occur with RFA. ${ }^{54}$

\section{Cryoablation}

Cryoablation involves freezing and thawing of tumors, resulting in tumor ablation. ${ }^{55-59}$ Cryotherapy can be used percutaneously or intraoperatively using intraoperative ultrasound and probes, and has become an important adjunct to surgical cytoreduction. Drawbacks include the large size of the probe, which causes increased risk for hemorrhage and higher rates of complications for larger metastases. More recently, smaller-gauge cryoprobes for percutaneous ablation, which allow placement of multiple probes, have been introduced simultaneously (PerCryo, Endocare Inc, Ervine, California). Image guidance is improved with use of CT, which clearly delineates the iceball for accurate visualization of the zone of treatment. Limited data remain for cryoablation treatment of neuroendocrine liver metastases, but it has potential and requires further investigation by interventional radiologists.

\section{Laser Interstitial Thermotherapy}

Using a Nd-YAG laser to create coagulative necrosis has been proposed for managing hepatic metastasis from neuroendocrine tumors. The laser fiber is introduced through a laser application kit, consisting of a cannulation needle, guide wire, sheath system with mandrin (10F, $20 \mathrm{~cm}$ in length), and special protective catheter (9F, $43 \mathrm{~cm}$ in length) that is closed at the end. This protective catheter, which is heat-resistant, prevents direct contact of the laser fiber with the tissue and enables safe and easy removal of the fiber post-therapy. The laser system is cooled with saline and therefore prevents carbonization of the laser fiber. The advantage of the laser application system is that it can be performed under MR guidance; this is of great value because the efficacy of the therapy can be evaluated simultaneously using MRI. ${ }^{60}$

\section{Conclusions}

The role of interventional radiologists in managing liver metastasis from neuroendocrine tumors is inte- gral to multidisciplinary care. Available techniques for patients with disseminated hepatic metastases include hepatic arterial embolization, chemoembolization, and radioembolization. RFA, cryotherapy, and, to a lesser extent, ethanol therapy serve as adjuncts to surgical cytoreduction when necessary.

\section{References}

1. Moertel CG, Johnson CM, McKusick MA, et al. The management of patients with advanced carcinoid tumors and islet cell carcinomas. Ann Intern Med 1994;120:302-309.

2. Carrasco $\mathrm{CH}$, Charnsangavej $\mathrm{C}$, Ajani J, et al. The carcinoid syndrome: palliation by hepatic artery embolization. AJR Am J Roentgenol 1986;147:149-154.

3. Ajani JA, Carrasco $\mathrm{CH}$, Charnsangavej $\mathrm{C}$, et al. Islet cell tumors metastatic to the liver: effective palliation by sequential hepatic artery embolization. Ann Intern Med 1988;108:340-344.

4. Clark OH, Ajani JA, Benson AB, et al. NCCN Clinical Practice Guidelines in Oncology: Neuroendocrine Tumors. Version 1, 2008. Available at: www.nccn.org/professionals/physician_gls/PDF, neuroendocrine.pdf. Accessed January 3, 2009.

5. Proye C. Natural history of liver metastasis of gastroenteropancreatic neuroendocrine tumors: place for chemoembolization. World J Surg 2001;25:685-688.

6. Blonski WC, Reddy KR, Shaked A, et al. Liver transplantation for metastatic neuroendocrine tumor: a case report and review of the literature. World J Gastroenterol 2005;11:7676-7683.

7. Sutcliffe R, Maguire D, Ramage J, et al. Management of neuroendocrine liver metastases. Am J Surg 2004;187:39-46.

8. Pichlmayr R, Weimann A, Oldhafer KJ, et al. Appraisal of transplantation for malignant tumours of the liver with special reference to early stage hepatocellular carcinoma. Eur J Surg Oncol 1998;24:60-67.

9. Le Treut YP, Delpero JR, Dousset B, et al. Results of liver transplantation in the treatment of metastatic neuroendocrine tumors. A 31-case French multicentric report. Ann Surg 1997;225:355-364.

10. Venook AP. Embolization and chemoembolization therapy for neuroendocrine tumors. Curr Opin Oncol 1999;11:38-41.

11. Strosberg JR, Choi J, Cantor AB, Kvols LK. Selective hepatic artery embolization for treatment of patients with metastatic carcinoid and pancreatic endocrine tumors. Cancer Control 2006;13:72-78.

12. Ruszniewski P. Interventional radiology: less invasive or less effective? In: Irvin M. Modlin KO, eds. A Century of Aadvances in Neuroendocrine Tumor Biology and Treatment. Hanover, Germany: Felsenstein CCCP; 2007.

13. Dominguez S, Denys A, Madeira I, et al. Hepatic arterial chemoembolization with streptozotocin in patients with metastatic digestive endocrine tumours. Eur J Gastroenterol Hepatol 2000;12:151-157.

14. Casadei R, Tomassetti P, Rossi C, et al. Treatment of metastatic glucagonoma to the liver: case report and literature review. Ital J Gastroenterol Hepatol 1999;31:308-312.

15. Lee SM, Forbes A, Williams R. Metastatic islet cell tumour with clinical manifestations of insulin and glucagon excess: successful treatment by hepatic artery embolization and chemotherapy. Eur J Surg Oncol 1988;14:265-268. 
Interventional Radiology for Neuroendocrine Liver Metastases

16. Ruszniewski P, Rougier P, Roche A, et al. Hepatic arterial chemoembolization in patients with liver metastases of endocrine tumors. A prospective phase II study in 24 patients. Cancer 1993;71:2624-2630.

17. Therasse E, Breittmayer F, Roche A, et al. Transcatheter chemoembolization of progressive carcinoid liver metastasis. Radiology 1993;189:541-547.

18. Roche A, Girish BV, de Baere T, et al. Trans-catheter arterial chemoembolization as first-line treatment for hepatic metastases from endocrine tumors. Eur Radiol 2003;13:136-140.

19. Diaco DS, Hajarizadeh $\mathrm{H}$, Mueller CR, et al. Treatment of metastatic carcinoid tumors using multimodality therapy of octreotide acetate, intra-arterial chemotherapy, and hepatic arterial chemoembolization. Am J Surg 1995;169:523-528.

20. Clouse ME, Perry L, Stuart K, Stokes KR. Hepatic arterial chemoembolization for metastatic neuroendocrine tumors. Digestion 1994;55(Suppl 3):92-97.

21. Stokes KR, Stuart K, Clouse ME. Hepatic arterial chemoembolization for metastatic endocrine tumors. J Vasc Interv Radiol 1993;4:341-345.

22. Perry LJ, Stuart K, Stokes KR, Clouse ME. Hepatic arterial chemoembolization for metastatic neuroendocrine tumors. Surgery 1994;116:1111-1116; discussion 1116-1117.

23. Diamandidou E, Ajani JA, Yang DJ, et al. Two-phase study of hepatic artery vascular occlusion with microencapsulated cisplatin in patients with liver metastases from neuroendocrine tumors. AJR Am J Roentgenol 1998;170:339-344.

24. Drougas JG, Anthony LB, Blair TK, et al. Hepatic artery chemoembolization for management of patients with advanced metastatic carcinoid tumors. Am J Surg 1998;175:408-412.

25. Desai DC, O'Dorisio TM, Schirmer WJ, et al. Serum pancreastatin levels predict response to hepatic artery chemoembolization and somatostatin analogue therapy in metastatic neuroendocrine tumors. Regul Pept 2001;96:113-117.

26. Ruszniewski P, Malka D. Hepatic arterial chemoembolization in the management of advanced digestive endocrine tumors. Digestion 2000;62(Suppl 1):79-83.

27. Roche A, Girish BV, de Baere T, et al. Prognostic factors for chemoembolization in liver metastasis from endocrine tumors. Hepatogastroenterology 2004;51:1751-1756.

28. Touzios JG, Kiely JM, Pitt SC, et al. Neuroendocrine hepatic metastases: does aggressive management improve survival? Ann Surg 2005;241:776-783; discussion 783-775.

29. Marrache F, Vullierme MP, Roy C, et al. Arterial phase enhancement and body mass index are predictors of response to chemoembolisation for liver metastases of endocrine tumours. Br J Cancer 2007;96:49-55.

30. Ho AS, Picus J, Darcy MD, et al. Long-term outcome after chemoembolization and embolization of hepatic metastatic lesions from neuroendocrine tumors. AJR Am J Roentgenol 2007;188:1201-1207.

31. Hajarizadeh $\mathrm{H}$, Ivancev $\mathrm{K}$, Mueller $\mathrm{CR}$, et al. Effective palliative treatment of metastatic carcinoid tumors with intra-arterial chemotherapy/chemoembolization combined with octreotide acetate. Am J Surg 1992;163:479-483.

32. Kim YH, Ajani JA, Carrasco CH, et al. Selective hepatic arterial chemoembolization for liver metastases in patients with carcinoid tumor or islet cell carcinoma. Cancer Invest 1999;17:474-478.

33. Gupta S, Yao JC, Ahrar K, et al. Hepatic artery embolization and chemoembolization for treatment of patients with metastatic carcinoid tumors: the M.D. Anderson experience. Cancer J 2003;9:261-267.

34. Kress $\mathrm{O}$, Wagner $\mathrm{HJ}$, Wied $\mathrm{M}$, et al. Transarterial chemoembolization of advanced liver metastases of neuroendocrine tumors-a retrospective single-center analysis. Digestion 2003;68:94-101.

35. Fiorentini G, Rossi S, Bonechi F, et al. Intra-arterial hepatic chemoembolization in liver metastases from neuroendocrine tumors: a phase II study. J Chemother 2004;16:293-297.

36. Artinyan A, Nelson R, Soriano P, et al. Treatment response to transcatheter arterial embolization and chemoembolization in primary and metastatic tumors of the liver. HPB (Oxford) 2008;10:396-404

37. Carrasco CH, Chuang VP, Wallace S. Apudomas metastatic to the liver: treatment by hepatic artery embolization. Radiology 1983;149:79-83.

38. Mavligit GM, Pollock RE, Evans HL, Wallace S. Durable hepatic tumor regression after arterial chemoembolization-infusion in patients with islet cell carcinoma of the pancreas metastatic to the liver. Cancer 1993;72:375-380.

39. Hanssen LE, Schrumpf E, Kolbenstvedt AN, et al. Recombinant alpha-2 interferon with or without hepatic artery embolization in the treatment of midgut carcinoid tumours. A preliminary report. Acta Oncol 1989;28:439-443.

40. Wangberg B, Westberg G, Tylen U, et al. Survival of patients with disseminated midgut carcinoid tumors after aggressive tumor reduction. World J Surg 1996;20:892-899; discussion 899.

41. Eriksson BK, Larsson EG, Skogseid BM, et al. Liver embolizations of patients with malignant neuroendocrine gastrointestinal tumors. Cancer 1998;83:2293-2301.

42. Loewe C, Schindl M, Cejna M, et al. Permanent transarterial embolization of neuroendocrine metastases of the liver using cyanoacrylate and lipiodol: assessment of mid- and long-term results. AJR Am J Roentgenol 2003;180:1379-1384.

43. Ruutiainen AT, Soulen MC, Tuite CM, et al. Chemoembolization and bland embolization of neuroendocrine tumor metastases to the liver. J Vasc Interv Radiol 2007;18:847-855.

44. Christante D, Pommier S, Givi B, Pommier R. Hepatic artery chemoinfusion with chemoembolization for neuroendocrine cancer with progressive hepatic metastases despite octreotide therapy. Surgery 2008;144:885-893; discussion 893-884.

45. McStay MK, Maudgil D, Williams M, et al. Large-volume liver metastases from neuroendocrine tumors: hepatic intraarterial 90Y-DOTA-lanreotide as effective palliative therapy. Radiology 2005;237:718-726.

46. King J, Quinn R, Glenn DM, et al. Radioembolization with selective internal radiation microspheres for neuroendocrine liver metastases. Cancer 2008;113:921-929.

47. Kennedy AS, Dezarn WA, McNeillie P, et al. Radioembolization for unresectable neuroendocrine hepatic metastases using resin 90Y-microspheres: early results in 148 patients. Am J Clin Oncol 2008;31:271-279.

48. Murthy R, Kamat P, Nunez R, et al. Yttrium-90 microsphere radioembolotherapy of hepatic metastatic neuroendocrine carcinomas after hepatic arterial embolization. J Vasc Interv Radiol 2008;19:145-151.

49. Rhee TK, Lewandowski RJ, Liu DM, et al. 90Y Radioembolization for metastatic neuroendocrine liver tumors: preliminary results from a multi-institutional experience. Ann Surg 2008;247:10291035 . 
Kvols et al.

50. Hellman P, Ladjevardi S, Skogseid B, et al. Radiofrequency tissue ablation using cooled tip for liver metastases of endocrine tumors. World J Surg 2002;26:1052-1056.

51. Giovannini M. Percutaneous alcohol ablation for liver metastasis. Semin Oncol 2002;29:192-195.

52. Livraghi T, Goldberg SN, Lazzaroni S, et al. Small hepatocellular carcinoma: treatment with radio-frequency ablation versus ethanol injection. Radiology 1999;210:655-661.

53. Lencioni RA, Allgaier HP, Cioni D, et al. Small hepatocellular carcinoma in cirrhosis: randomized comparison of radio-frequency thermal ablation versus percutaneous ethanol injection. Radiology 2003;228:235-240.

54. Atwell TD, Charboneau JW, Que FG, et al. Treatment of neuroendocrine cancer metastatic to the liver: the role of ablative techniques. Cardiovasc Intervent Radiol 2005;28:409-421.
55. Shafir M, Shapiro R, Sung M, et al. Cryoablation of unresectable malignant liver tumors. Am J Surg 1996;171:27-31.

56. Cozzi PJ, Englund R, Morris DL. Cryotherapy treatment of patients with hepatic metastases from neuroendocrine tumors. Cancer 1995;76:501-509.

57. Sheen AJ, Poston GJ, Sherlock DJ. Cryotherapeutic ablation of liver tumours. Br J Surg 2002;89:1396-1401.

58. Duperier T, Ali A, Pereira S, et al. Laparoscopic cryoablation of a metastatic carcinoid tumor. J Laparoendosc Adv Surg Tech A 2001;11:105-109.

59. Shapiro RS, Shafir M, Sung M, et al. Cryotherapy of metastatic carcinoid tumors. Abdom Imaging 1998;23:314-317.

60. Vogl TJ, Naguib NN, Zangos $\mathrm{S}$, et al. Liver metastases of neuroendocrine carcinomas: interventional treatment via transarterial embolization, chemoembolization and thermal ablation. Eur J Radiol 2009; in press. 